\title{
Infection of sparrows (Passer domesticus) and different mice strains with Lawsonia intracellularis ${ }^{1}$
}

\author{
Aline de M. Viott ${ }^{2}$, Silvia A. França ${ }^{3}$, Fábio A. Vannucci ${ }^{4}$, Eduardo C.C. Cruz Jr ${ }^{3}$, \\ Mirella C. Costa ${ }^{3}$, Connie J. Gebhart ${ }^{4}$ and Roberto M.C. Guedes ${ }^{3 *}$
}

\begin{abstract}
Viott A.M., França S.A., Vannucci F.A., Cruz Jr E.C.C., Costa M.C., Gebhart C.J. \& Guedes R.M.C. 2013. Infection of sparrows (Passer domesticus) and different mice strains with Lawsonia intracellularis. Pesquisa Veterinária Brasileira 33(3):372-378. Departamento de Clínica e Cirurgia Veterinárias, Escola de Veterinária, Universidade Federal de Minas Gerais, Avenida Antonio Carlos 6627, Pampulha, Belo Horizonte, MG 31123-901, Brazil.E-mail: guedesufmg@gmail.com

The susceptibility of sparrows (Passer domesticus) and strains of mice (Swiss, BALB/c, C-57 and DB-A) to Lawsonia intracellularis infection was studied. Thirty-two sparrows were inoculated with pure culture of $L$. intracellularis and eleven received sham inoculum. Feces were collected on $-1,7,14$ and 21 days post infection (dpi) for detection of L. intracellularis by PCR. After 21 days, all sparrows were euthanized and the tissues processed for histology and immunohistochemistry (IHC). One hundred sixty mice of four different strains ( $n=40$, per strain) were used. For each mouse strain, 16 animals received mucosa homogenate from a pig infected with $L$. intracellularis, 16 received pure culture of $L$. intracellularis and eight animals received sham inoculum. Two control and four inoculated mice from each group were euthanized on 7, 14, 21 and $28 \mathrm{dpi}$. Sections of intestine were collected for histologic analysis and IHC and pooled feces were collected for L. intracellularis PCR. None of the sparrows had any histologic lesions characteristic of proliferative enteropathy or antigen labeling by IHC. All sparrow fecal samples were negative by PCR. All mice strains studied had histopathological lesions typical of PE and IHC labeling consistent with L. intracellularis infection, especially those animals inoculated with pure culture. The most severe lesions were observed in DB-A and Swiss mice. Fecal shedding was detected in all mice strains, with peak at $14 \mathrm{dpi}$. We conclude that sparrows do not seem to be relevant in the epidemiology of L. intracellularis. The results showed variations in the lesions among the four mice strains used.
\end{abstract}

INDEX TERMS: Lawsonia intracellularis, mouse, Mus musculus, sparrow, Passer domesticus, experimental infection.

RESUMO.- [Infecção de pardais (Passer domesticus) e diferentes linhagens de camundongos com Lawsonia intracellularis.] A susceptibilidade de pardais (Passer domesticus) e linhagens de camundongos (Swiss, BALB / C,

\footnotetext{
${ }^{1}$ Received on April 7, 2012.

Accepted for publication on September 13, 2012.

${ }^{2}$ Laboratório de Patologia Veterinária, Universidade Federal do Paraná (UFPR), Pioneiro 2153, Jd. Dallas, Palotina, PR 85950-000, Brazil.

3 Departamento de Clínica e Cirurgia Veterinárias, Escola de Veterinária, Universidade Federal de Minas Gerais (UFMG), Av. Antonio Carlos 6627, Belo Horizonte, MG 31123-901, Brazil. *Corresponding author: guedesufmg@gmail.com

${ }^{4}$ Department of Veterinary and Biomedical Sciences, University of Minnesota, Minnesota 55108, USA.
}

C-57 e DB-A) à infecção por L. intracellularis foi testada. Trinta e dois pardais foram inoculados com cultura pura de L. intracellularis e onze receberam placebo. As fezes foram coletadas nos dias -1, 7, 14 e 21 após a infecção (dpi) para a detecção de Lawsonia intracellularis por PCR. Após 21 dias, todos os pardais foram eutanasiados e os tecidos processados para a realização da histologia e imuno-histoquímica (IHQ). Cento e sessenta camundongos de quatro linhagens diferentes $(n=40$, por linhagem) foram utilizados. Para cada linhagem de camundongo, 16 receberam homogeneizado de mucosa preparado a partir de um suíno infectado com L. intracellularis, 16 receberam cultura pura de L. intracellularis e oito animais receberam placebo. Dois camundongos controle e quatro camundongos inoculados 
de cada grupo foram sacrificados aos 7, 14, 21 e 28 dpi. Seções de intestino foram coletadas para análise histológica e IHQ e amostras de fezes foram coletadas para a realização da PCR para detecção de L. Intracellularis. Nenhum dos pardais apresentou lesões histológicas características da enteropatia proliferativa ou marcação positiva por meio da IHQ. As amostras de fezes dos pardais foram negativas na PCR. Todas as linhagens de camundongos estudadas tinham lesões histopatológicas típicas de enterite proliferativa e IHQ positiva para a infecção por L. intracellularis, especialmente aqueles animais inoculados com a cultura pura. As lesões mais graves foram observadas em camundongos DB-A e Swiss. A eliminação fecal foi detectada em todas as linhagens de camundongos, com pico 14 dpi. Conclui-se que os pardais não são relevantes na disseminação da $L$. intracellularis. Os resultados mostraram variações nas lesões entre as quatro linhagens de camundongos utilizadas, indicando o potencial risco que os camundongos representam na transmissão de L. Intracellularis.

TERMOS DE INDEXAÇÃO: Lawsonia intracellularis; camundongo, Mus musculus, pardais, Passer domesticus, infecção experimental.

\section{INTRODUCTION}

Lawsonia intracellularis is a Gram-negative, obligate intracellular bacterium that causes proliferative enterophaty (PE) in pigs (McOrist et al. 1995, Gebhart \& Guedes 2004, Kroll et al. 2005), and in many other animal species (Cooper \& Gebhart 1998). PE is characterized macroscopically by intestinal mucosal thickening and histopathologically by mucosal hyperplasia, mainly in the ileum but also in the cecum and colon (Lawson \& Gebhart 2000).

PE causes important economic losses in the swine industry around the world (Jacobson et al. 2010). In the acute and chronic forms, losses are represented by reduced weight gain and diarrhea in affected pigs, costs associated with control and mortality in young adults and animals close to market age. The subclinical form induces significant decrease in performance of infected animals (Lawson \& Gebhart 2000). Diagnosis of L. intracellularis infection is based on PCR assay of fecal or intestinal samples, detection of specific IgG in serum, and by in situ hybridization, histopathology and immunohistochemical examination of formalin-fixed samples of intestines for the detection of intracellular bacteria in epithelial cells (Guedes \& Gebhart 2003b).

Little is known about the epidemiology of this disease (Jacobson et al. 2010). It is of great interest to establish possible mechanisms of transmission of L. intracellularis (Guedes \& Gebhart 2003b). Subclinically affected pigs are the main source of infection to susceptible animals, however, outbreaks of PE on farms never before populated or replaced with animals from farms with no clinical history of the disease have been discussed (Collins et al. 2011). Recently, a study demonstrated the risk that rodents pose in the transmission of L. intracellularis to naive pigs and highlights the need for PE eradication programs to focus on the removal of rodents from pig farms (Coolins et al. 2011). Still exist the possibility that wild animals or birds, acting as vectors in spreading the disease among farms (Friedman et al. 2008, Pusterla et al. 2008).
There have been reports of PE in birds, such as the emu (Dromaius novaehollandiae) (Lemarchand et al. 1997) and ostrich (Struthio camelus) (Cooper et al. 1997, Cooper \& Gebhart 1998). Pusterla et al. (2008) studied the occurrence of L. intracellularis in Brewer's Blackbird (Euphagus cyanocephalus), but did not find evidences of infection in this species. To the best of our knowledge, there is no other study evaluating L. intracellularis infection in Passeriformes.

Rats and mice represent a potential reservoir, particularly for pigs, where the environment is likely to be cohabited by rodents (Collins et al. 2011, Pusterla et al., 2012). The susceptibility of laboratory mice to $L$. intracellularis was proven by experimental infection (Smith et al. 2000) however, the occurrence of PE lesions varies among different mouse strains. For instance, A/J mice (Murakata et al. 2008), C57BL/6, BALB/c (Go et al. 2005, Collins et al. 1999) and ICR (Go et al. 2005) were reported not to exhibit signs of infection. However, Murakata et al. (2007) showed that there are differences with respect to the establishment of lesions of PE in mice according to the type of inoculum used. This study demonstrated that mice inoculated with intestinal mucosa homogenate extracted from PE-affected rabbits had more severe lesions than those inoculated with pig intestinal homogenate. Therefore, the susceptibility of mice seems to be related to the lineage of animals and the type of inoculum used.

The susceptibility of sparrows (Passer domesticus) to L. intracellularis infection after experimental inoculation with pure culture was evaluated in order to access the potential epidemiological importance of Passeriformes in the transmission of the bacteria. The establishment of a $L$. intracellularis challenge model in different strains of mice (BALB/c, C57, DB/A2 and Swiss) using intestinal mucosa homogenate extracted from PE-affected pigs and pure culture of the bacteria as inoculum was also studied.

\section{MATERIALS AND METHODS}

\section{Hamsters, sparrows and mice}

Initially, a hamster bioassay was performed in order to demonstrate the pathogenicity of the Lawsonia intracellularis pure culture inoculum. Eight 18-day-old hamsters weighing 18.5g on average from the vivarium of the Universidade Federal de Minas Gerais were used. All hamsters were housed in plastic boxes (30x20x13 cm) receiving commercial diet and water ad libitum.

Forty-three adult sparrows (Passer domesticus), weighing $21.89 \mathrm{~g} \pm 1.342$ were captured in the metropolitan area of Belo Horizonte, Brazil, without distinction of sex or age. All animals were kept in individual cages $(40 \times 19 \times 35 \mathrm{~cm})$ and received food and water ad libitum.

Forty 3 to 4 -week-old, male mice weighing 13.6g \pm 2.341 from each of the four strains (BALB/c, C57, DB/A2 and Swiss) were used. All animals were housed in plastic cages $(30 \times 20 \times 13 \mathrm{~cm})$, with eight animals per cage, receiving food and water ad libitum. All mice were acclimatized for one week before inoculation. All experiments were conducted in accordance with the Universidade Federal de Minas Gerais Ethics Committee (document number 9/2003 and $162 / 2008$, respectively).

Pure culture and intestinal homogenate inoculum

The L. intracellularis isolate PHE/MN1-00 (ATCC PTA-3457), 
originally isolated from a pig with the hemorrhagic form of PE in the U.S., was used as inoculum for hamsters, sparrows and mice. Bacteria were grown in McCoy cells (ATCC CRL 1696), as previously described (Guedes \& Gebhart 2003a, Guedes \& Gebhart 2003b, Guedes \& Gebhart 2003c). Briefly, from frozen stocks of the bacteria, L. intracellularis was passed in cell culture up to nine passages. Cells were then lysed and a bacterial suspension was prepared in sucrose-potassium-glutamate (SPG) buffer with $5 \%$ fetal calf serum (FCS). Aliquots of this suspension containing approximately $7.75 \times 10^{7} \mathrm{~L}$. intracellularis per ml were stored at $-80^{\circ} \mathrm{C}$ and thawed immediately prior to inoculation of hamsters, sparrows and mice.

Before preparing the mucosa intestinal homogenate from a pig naturally infected, L. intracellularis infection was confirmed in tissue samples by histology and immunohistochemistry (Guedes \& Gebhart 2003b). PE-affected swine intestines were utilized for the preparation of the intestinal homogenate inoculum. The intestines were rapidly thawed in warm water and the mucosa scraped using clean glass slides. The scraped mucosa was combined with SPG and homogenized in a blender for $2 \mathrm{~min}$. Then, the inoculum was aliquoted and kept at $-80^{\circ} \mathrm{C}$ until use. Aliquots of suspensions containing approximately $8.9 \times 10^{8} \mathrm{~L}$. intracellularis per $\mathrm{mL}$ were thawed and used on the day of inoculation. Pathogenicity of L. intracellularis present in the intestinal homogenated was evaluated and demonstrated in a previous study conducted by our group that used the same material (Vanucci et al. 2010).

Quantification of pure culture and intestinal homogenate inocula was accomplished by preparing 10 fold serial dilutions of the inoculum in phosphate buffered saline (PBS), coating 15-well glass slides with $10 \mathrm{ml}$ of each dilution, drying at $37^{\circ} \mathrm{C}$, fixing with cold acetone and staining by indirect immunoperoxidase using a polyclonal antibody specific for L. intracellularis (Guedes \& Gebhart, 2003c). The numbers of organisms were counted under light microscopy.

\section{Experimental design}

Hamster control for pathogenicity. Each of the five hamsters was orally inoculated with $0.5 \mathrm{~mL}$ of pure culture of $L$. intracellularis PHE/MN1-00 (ATCC PTA-3457), containing approximately $7.75 \times 10^{7}$ organisms per $\mathrm{mL}$. The three remaining hamsters received SPG as a sham inoculum. All animals were euthanized 28 dpi after inoculation and the infection was evaluated in the ileum, cecum, colon and rectum.

Sparrows. On day 0 (D0) 32 sparrows were inoculated by the oro-esophageal route with $0.5 \mathrm{ml}$ of pure culture of $L$. intracellularis using a urethral probe (№ 4) attached to a syringe. Eleven sparrows in the control group were inoculated with SPG (sham inoculums) in the same way on D0. Fecal samples were collected from each sparrow at $-1,7,14$ and $21 \mathrm{dpi}$. In order to collect fecal samples, the bottoms of the cages were covered with plastic for a period of 8 hours, and then the fecal material collected and stored at $-20^{\circ} \mathrm{C}$ until tested by PCR. On day 21 post inoculation all animals were euthanized, necropsied. The liver, gizzard and all intestinal segments were immediately collected for histology.

Mice. From each of the four mice strains, 16 animals were inoculated with $0.5 \mathrm{ml}$ of pure culture of L. intracellularis, 16 with $0.5 \mathrm{ml}$ of intestinal homogenate and eight with SPG (sham inoculum) using an intragastric gavage. Four mice from each infected and two from the control groups were humanely euthanized for post mortem evaluation at 7, 14, 21 and $28 \mathrm{dpi}$. Intestinal samples (duodenum, jejunum, ileum, cecum and colon) were immediately collected after euthanasia for histological examination. Fecal samples were taken in the same days of euthanasia by transferring mice to clean plastic cages with no bedding for a period of two hours. A pool of fecal samples was collected from each cage and stored at $-20^{\circ} \mathrm{C}$ for further analysis.

\section{Histology and immunohistochemistry}

Tissue samples from sparrows, hamsters and mice were fixed in $10 \%$ neutral buffered formalin, embedded in paraffin wax, and sectioned $(5 \mathrm{~mm})$. One section was stained with haematoxylin and eosin (HE) and another by immunohistochemistry (IHC) with polyclonal antibody specific to L. intracellularis (Guedes \& Gebhart 2003c) using the method of peroxidase-labeled Streptavidin (Dako, Corporation, LSAB+, cat. K0690). Positive immunoreactivity was detected with 3-amino-9-ethyl-carbazol (AEC) (Dako, Corporation, AEC Substrate-Chromogen, cat. K3464).

Histologic lesions were scored according to the intensity: 0, none; 1 , mild; 2, moderate; and, 3, severe. An identical scoring system was used to record the degree of immunolabelling of $L$. intracellularis antigen.

\section{PCR technique}

Sparrows. DNA was extracted from feces according to Boom et al. (1990). Primers A and B with a 310 bp product were used for the PCR assay (Jones et al. 1993). PCR products were separated on $1 \%$ agarose gel stained with ethidium bromide.

Mice. DNA extraction from fecal samples was also performed according to Boom et al. (1990). A nested PCR assay according Jones et al. (1993) was performed in order to improve the sensitivity. Saline solution was used as negative control in all reactions and a sample of pure culture of $L$. intracellularis was used as a positive control. PCR products were separated on $1 \%$ agarose gel stained with ethidium bromide.

\section{RESULTS}

\section{Hamsters}

One of the hamsters inoculated with pure culture had $10 \mathrm{~cm}$ of intestinal macroscopic changes suggestive of PE, subsequently confirmed by HE and IHC. The other four hamsters inoculated with pure culture of Lawsonia intracellularis had hyperplasia of enterocytes and the antigen was detected by IHC, confirming the pathogenicity of the inoculum. No sign of infection by L. intracellularis was observed in control animals.

\section{Sparrows}

No clinical signs or macroscopic lesions were observed in the liver, gizzard and intestinal segments. Sparrows inoculated with the pathogenic isolate of L. intracellularis had no histological lesions compatible with PE. Two animals had focal mild positive antigen labeling detected by IHC in macrophages of the lamina propria of the jejunum. In addition, four other sparrows had mild positive label in the cytoplasm of macrophages in the liver. None of the fecal samples were positive by PCR. No sign of gross or histological lesions, or IHC labeling or any PCR positive feces were observed in control animals.

\section{Mice}

Histopathology, IHQ and PCR results are summarized in table 1. No diarrhea or other clinical signs were observed in mice inoculated with either mucosa homogenate or pure culture, or sham inoculum. Macroscopically, one 
Table 1. Histopathological lesions, immunohistochemical (IHC) labeling intensity and pooled fecal PCR results in the intestines of mice infected with mucosa homogenate or pure culture on 7, 14, 21 and 28 days post-infection (dpi)

\begin{tabular}{|c|c|c|c|c|c|c|c|c|c|c|c|c|}
\hline \multirow{2}{*}{$\begin{array}{l}\text { Mouse Strain } \\
\text { Inoculum }\end{array}$} & \multicolumn{4}{|c|}{$\begin{array}{c}\text { Histopathology }{ }^{\mathrm{a}} \\
\text { Dpi }\end{array}$} & \multicolumn{4}{|c|}{$\begin{array}{c}\text { Immunohistochemistry }^{\mathrm{b}} \\
\text { Dpi }\end{array}$} & \multicolumn{4}{|c|}{$\begin{array}{c}\text { Fecal PCR } \\
\text { Dpi }\end{array}$} \\
\hline & 7 & 14 & 21 & 28 & 7 & 14 & 21 & 28 & 7 & 14 & 21 & 28 \\
\hline \multicolumn{13}{|l|}{ Swiss } \\
\hline $\begin{array}{l}\text { Mucosa } \\
\text { Homogenate }\end{array}$ & $0 / 0 / 0 / 0$ & $1 / 1 / 1 / 0$ & $0 / 0 / 0 / 0$ & $0 / 0 / 0 / 0$ & $0 / 0 / 0 / 0$ & $1 / 1 / 1 / 0$ & $0 / 0 / 0 / 0$ & $0 / 0 / 0 / 0$ & - & + & - & - \\
\hline $\begin{array}{l}\text { Pure culture } \\
\text { BALB/c }\end{array}$ & $1 / 2 / 1 / 1$ & $3 / 3 / 2 / 3$ & $0 / 0 / 0 / 0$ & $0 / 0 / 0 / 0$ & $1 / 1 / 1 / 1$ & $3 / 3 / 2 / 2$ & $0 / 0 / 0 / 0$ & $0 / 0 / 0 / 0$ & + & + & - & - \\
\hline $\begin{array}{l}\text { Mucosa } \\
\text { Homogenate }\end{array}$ & $0 / 0 / 0 / 0$ & $1 / 1 / 0 / 0$ & $0 / 0 / 0 / 0$ & $0 / 0 / 0 / 0$ & $0 / 0 / 0 / 0$ & $1 / 0 / 0 / 0$ & $0 / 0 / 0 / 0$ & $0 / 0 / 0 / 0$ & - & + & - & - \\
\hline $\begin{array}{l}\text { Pure culture } \\
\text { C-57 }\end{array}$ & $1 / 1 / 1 / 1$ & $1 / 1 / 0 / 0$ & $0 / 0 / 0 / 0$ & $0 / 0 / 0 / 0$ & $1 / 1 / 1 / 1$ & $1 / 1 / 0 / 0$ & $0 / 0 / 0 / 0$ & $0 / 0 / 0 / 0$ & - & + & - & - \\
\hline $\begin{array}{l}\text { Mucosa } \\
\text { Homogenate }\end{array}$ & $0 / 0 / 0 / 0$ & $0 / 0 / 0 / 0$ & $0 / 0 / 0 / 0$ & $0 / 0 / 0 / 0$ & $0 / 0 / 0 / 0$ & $1 / 0 / 0 / 0$ & $0 / 0 / 0 / 0$ & $0 / 0 / 0 / 0$ & - & - & - & - \\
\hline $\begin{array}{l}\text { Pure culture } \\
\text { DB-A }\end{array}$ & $1 / 1 / 1 / 1$ & $1 / 2 / 1 / 1$ & $1 / 1 / 0 / 0$ & $0 / 0 / 0 / 0$ & $1 / 1 / 1 / 0$ & $1 / 1 / 1 / 1$ & $1 / 0 / 0 / 0$ & $0 / 0 / 0 / 0$ & + & + & - & - \\
\hline $\begin{array}{l}\text { Mucosa } \\
\text { Homogenate }\end{array}$ & $1 / 1 / 1 / 0$ & $1 / 1 / 1 / 0$ & $1 / 1 / 1 / 1$ & $0 / 0 / 0 / 0$ & $1 / 1 / 1 / 0$ & $1 / 1 / 0 / 0$ & $1 / 1 / 1 / 1$ & $0 / 0 / 0 / 0$ & + & + & + & - \\
\hline Pure culture & $1 / 1 / 2 / 1$ & $3 / 3 / 2 / 1$ & $2 / 2 / 2 / 1$ & $1 / 1 / 0 / 0$ & $1 / 2 / 1 / 1$ & $3 / 3 / 2 / 1$ & $1 / 2 / 2 / 1$ & $1 / 1 / 0 / 0$ & + & + & + & - \\
\hline
\end{tabular}

DB-A mice inoculated with pure culture had thickening of the cecum and ileum wall at 14 dpi (Fig.1). All mice strains studied had histopathological lesions suggestive of $L$. intracellularis infection, but the severity of the lesions varied among mice strains, type of inoculum and period post-inoculation.

The main histological lesions observed consisted of mild to severe multifocal proliferation of epithelial cells of the crypts of Lieberkühn in the small intestine (ileum) and mucous glands of the large intestine (cecum). The proliferative lesions were more frequently observed in the cecum. At the tip of some intestinal villi, there was a focal proliferation of epithelial cells with ample and abundant cytoplasm. This lesion was common 7 dpi. Crypts were elongated and hyperplastic due to increased number of immature enterocytes and absence of goblet cells. This lesion was observed in isolated crypts or large segments of the small and large intestines, especially in animals that were inoculated

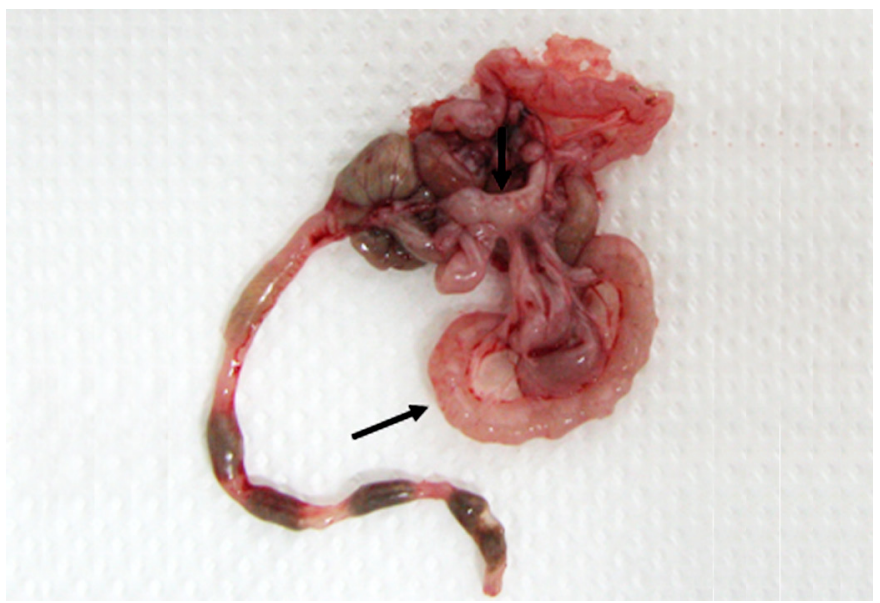

Fig.1. DB-A mouse inoculated with pure culture at 14 dpi. Demonstrating thickening and roughness of the wall of the cecum and ileum (arrows). with pure culture and, less frequently, in animals inoculated with mucosa homogenate. Inflammatory reaction was not observed in L. intracelullaris-infected mice. None of the control mice had any histological or immunohistochemical changes (Fig.2A and 2B).

Upon histological examination, BALB/C mice had mild lesions on 7 and 14 dpi (Fig.2C). The proliferative changes were more frequently seen in crypts located near Peyer's patches of the cecum. The C57 strain showed mild histological alterations until $21 \mathrm{dpi}$. The lesions were most frequent at $14 \mathrm{dpi}$. The DB-A mice had lesions until the end of the experiment ( $28 \mathrm{dpi}$ ). Lesions in this strain were more intense on 14 and $21 \mathrm{dpi}$. On days 7 and $28 \mathrm{dpi}$ the histological lesions were mild and observed in isolated crypts (Fig. 2E). Swiss mice had mild lesions on $7 \mathrm{dpi}$ and severe lesions on $14 \mathrm{dpi}$, and no change was detected after this period (Fig. 2G). Positive antigen labeling was observed at lesion sites and varied depending on the intensity of the lesion (mild to severe) (Table 1) (Fig.2D, 2F, 2H). Positive staining was observed in the tip of some intestinal villi, most often on $7 \mathrm{dpi}$. As the lesions were resolving, antigen detection in affected enterocytes decreased, becoming more frequently observed in the lamina propria and lymphoid tissue of Peyers patches.

Results of fecal PCR were compatible with histologic lesions. Swiss mice inoculated with pure culture were shedding L. intracellularis on D7. On day 14, Swiss mice inoculated with pure culture and intestinal homogenate had fecal PCR positive results. BALB/C mice inoculated with both types of inocula were positive by PCR only on $14 \mathrm{dpi}$. C57 mice inoculated with pure culture shed the bacteria on 7 and $14 \mathrm{dpi}$ while those inoculated with mucosa homogenate were negative throughout the experiment. Pure culture and intestinal homogenate inoculated DB-A mice were positive by PCR on 7, 14, and 21 dpi (Table I). All control mice were fecal PCR negative. 


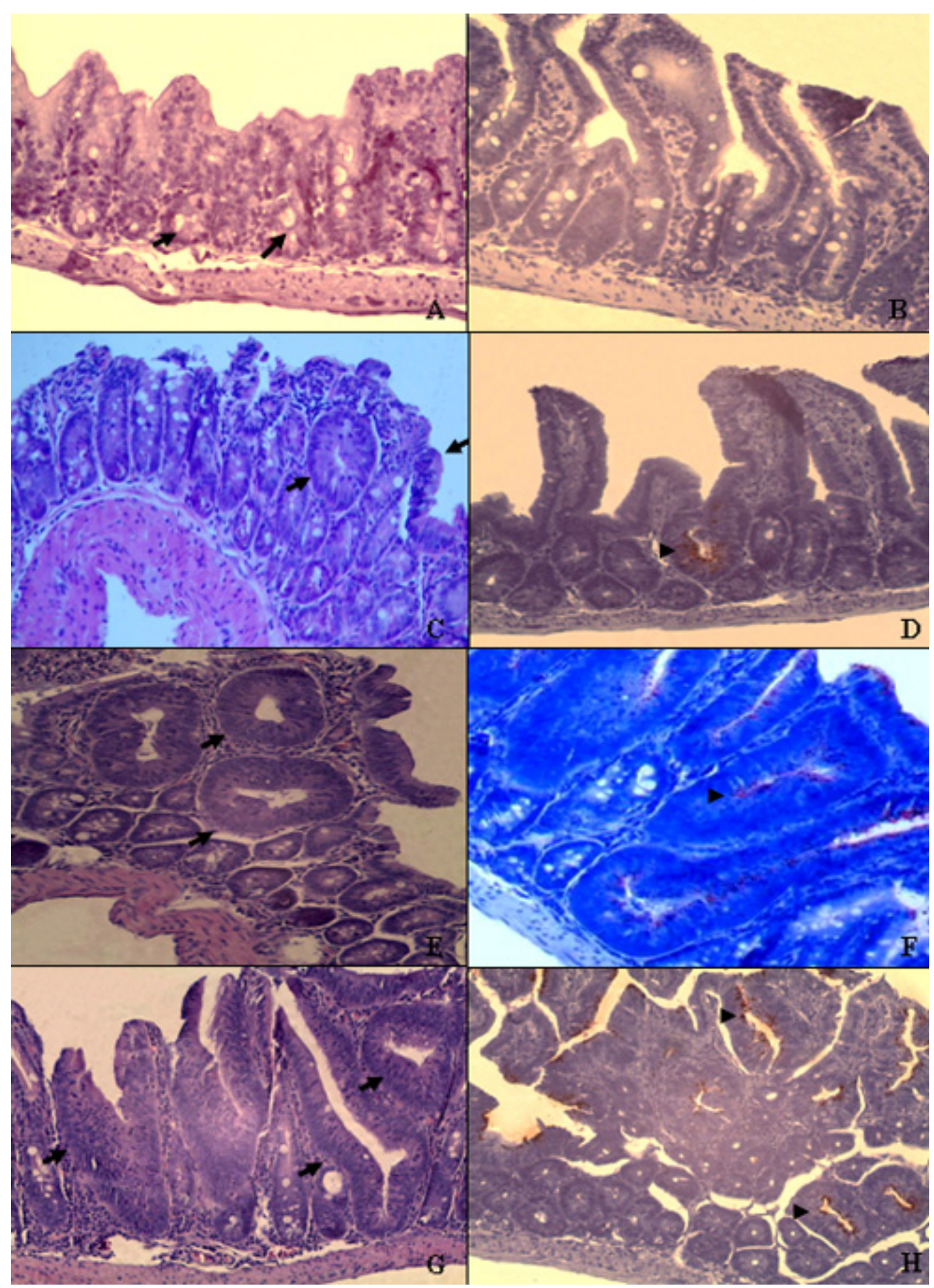

Fig.2. (A) Ileum, Swiss mouse inoculed with sham inoculum, $7 \mathrm{dpi}$. Normal epithelial overlayer with marked number of globet cells. HE, bar $=50 \mu \mathrm{m}$. (B) Ileum, DB-A mouse inoculed with sham inoculum, 14 dpi. No immunohistochemical labeling is observed. IHQ, bar $=50 \mu \mathrm{m}$. (C) Cecum, Balb mouse inoculated with mucosa homogenate, $14 \mathrm{dpi}$. There is mild focal hyperplasia of the intestinal crypts and mucosa apices (arrows). HE, bar $=50 \mu \mathrm{m}$. (D) Ileum, C-57 mouse inoculated with pure culture, $7 \mathrm{dpi}$. Multifocal mild label in hyperplasic crypt (arrows head). IHQ, bar $=50 \mu \mathrm{m}$. (E) Cecum, DB-A mouse inoculed with pure culture, $21 \mathrm{dpi}$. Multifocal moderate epithelial hyperplasia of crypts (arrows). HE, bar $=50 \mu \mathrm{m})$. (F) Ileum, DB-A mouse inoculed with pure culture, $21 \mathrm{dpi}$. Multifocal moderate label on the crypts apice (arrows head). IHQ, bar $=50 \mu \mathrm{m})$. (G) Ileum of Swiss mouse inoculated with pure culture, $14 \mathrm{dpi}$. Severe epithelial hyperplasia of crypts. The crypts have elongated cells with large amounts of immature enterocytes and absence of goblet cells (arrows). HE, bar $=50 \mu \mathrm{m}$ ). (H) Ileum, Swiss mouse inoculated with pure culture, $14 \mathrm{dpi}$. Intense immunohistochemical labeling (arrows head). IHQ bar $=50 \mu \mathrm{m}$. 


\section{DISCUSSION}

This study demonstrated the susceptibility of different strains of mice and the resistance of sparrows to experimental Lawsonia intracellularis infection. Different animal species may be susceptible to a pathogen at different levels, especially in cases of an intracellular microorganism. In order to infect host cells, the bacteria need to adhere to and penetrate the cell, and this requires complex mechanisms of cellular invasion. Then, the bacteria have to evade the intracellular lysosomal system and multiply in the host cell in order to progress the infection (Olsen et al. 2004).

Sparrows are ubiquitous species, capable of flying 6 to 8 kilometers a day (Fitzwater 1994), and they are found in close contact with pigs in different production systems in Brazil. As a result, they may be relevant in PE epidemiology. However, our study suggests the lack of susceptibility of sparrows to L. intracelullaris infection. To date, ostrich and emu are the only avian species reported to be naturally infected with L. intracellularis. Actually, the justification of the cloaca evaluation in sparrows was due to the fact that this segment was reported to be the infection site in these avian species (Cooper et al. 1997, Lemarchand et al. 1997). Experimental infection studies with chickens (Gallus gallus) and the attempt to detect natural infection in Brewer's Blackbirds (Euphagus cyanocephalus) resulted in no detectable lesion or infection (Collins et al. 1999, Pusterla et al. 2008, Pusterla et al., 2012).

In six sparrows slight antigen labeling was observed in the lamina propria of the intestine or in the liver. In these cases, the labeled antigen did not have the form of the intact bacteria, indicating only the presence of antigenic fragments thereof. It is possible that some bacteria fragments that were able to invade enterocytes passed through the cell membrane to the basal lamina propria, were internalized by antigen-presenting cells and drained to lymphoid tissue and liver. Detection of L. intracellularis antigen in lymph nodes of affected animals has been reported previously (Segalés et al. 2001, Guedes \& Gebhart 2003a).

All fecal samples collected from inoculated sparrows on $-1,7,14$ and 21 dpi were negative by PCR. These results are similar to another study in which chickens were experimentally infected (Collins et al. 1999). Among the hypotheses that could explain this phenomenon; is that the $L$. intracellularis is not capable to cause active infection in sparrows, the presence of large numbers of specific inhibitors of the PCR reaction in the feces or the low levels of shedding of bacteria in this species.

Our results demonstrate a significant variation of lesions and $L$. intracellularis infection among the four mice strains studied. DB-A and Swiss mice strains were the most susceptible to PE lesions, while the lesions in BALB/c and C-57 were mild. These differences in susceptibility to infectious agents have been previously known, and the genetic basis for these differences remains to be determined (Collins et al. 1999, Fortier et al. 2005, Murakata et al. 2008).

A comparative study of strains isolated from different animal species, based on the $16 \mathrm{~S}$ ribosomal DNA sequencing of the bacteria, showed no difference between them, although differences in outer proteins may exist (Cooper
\& Gebhart 1998, Murakata et al. 2008). Guedes and Gebhart (2003c), using monoclonal antibodies (MAbs 2001 and IG4 MAbs) and one polyclonal antibody (1999 PABs) for L. intracellularis, demonstrated through Western blot analysis that all $L$. intracellularis isolates, except one strain from a hamster, showed reactivity for all antibodies; which may indicate some difference in outer membrane proteins of the hamster isolate. Vanucci et al (2012) demonstrated evidences of host adaptation in L. intracellularis infections in swine and horses. In their study strong lesions and clinical signs were observed when the animals were challenged with an inoculum species specific. It was interesting to note the susceptibility of the Swiss mice strain, a common conventional laboratory strain that has never been reported or described as PE susceptible or a model candidate. The Swiss mouse is an excellent experimental model for the study of infectious diseases (Fortier et al. 2005) and may in the future be used in trials of PE.

L. intracellularis infection is characterized by thickening of the intestinal mucosa and histopathologically by epithelium hyperplasia (Lawson \& Gebhart 2000). Both lesions were observed in mice in this study proving a successful infection. Mice inoculated with pure culture seemed to have more severe histological lesions than those inoculated with mucosa homogenate. A previous study in pigs (Guedes \& Gebhart 2003a), which compared pure culture and intestinal homogenate as inocula, showed no differences in the severity of lesions or level of infection. The major advantage of the pure culture inoculum is the rigid control and absence of any other confounding bacteria or tissue factors (Guedes \& Gebhart 2003a). The success of pure culture may be explained by bacterial integrity, since there are more dead bacteria in the intestinal homogenate than in the pure culture.

Immunohistochemical examination of lesions in mice demonstrated an antigen labeling variation depending on the severity of the lesion. In pigs there is a relationship between histological lesion and immunohistochemical label (Lawson \& Gebhart 2000, Kroll et al. 2005) and the same seems to happen in mice. Boutrup et al. (2010) observed that $L$. intracellularis could be found within epithelial cells on the top of the villi, indicating infection in mature enterocytes, implying that these cells are also a target for the bacterium. This may be one possible explanation for the presence of antigens at the apex of the villi at $7 \mathrm{dpi}$ in small intestines of all mice strains tested. Less severe $L$. intracellular infections were more frequently observed in crypts, near the Peyer's patches or located in the lamina propria or in the cytoplasm of macrophages. Such changes may contribute to the elimination of the pathogenic organisms and to the return to a normal epithelial architecture (Smith \& Lawson 2001).

PCR is believed to be the most effective method for the detection of L. intracellularis in live animals (Kroll et al. 2005). According to Jones et al. (1993), conventional PCR can detect as low as $10^{3} \mathrm{~L}$. intracellularis organisms per gram of feces. Using PCR we could demonstrate that mice have different shedding patterns when compared to swine. Pigs can shed the bacteria from seven days to over twelve 
weeks post inoculation (Kroll et al. 2005) while DB-A mice shed no later than the $21 \mathrm{dpi}$, based on the present study. Nevertheless, typical major lesions and bacterial shedding occurred in mice strains $14 \mathrm{dpi}$, similar to what is described in pigs and rats (Collins et al. 2011, Macintyre et al. 2003).

\section{CONCLUSIONS}

There is only a limited amount of knowledge of factors contributing to the transmission of Lawsonia intracellularis.

It was demonstrated that sparrows (Passer domesticus) are not infected by L. intracellularis and should not be considered a reservoir. Nevertheless, more studies have to be performed in different passeriform species.

On the contrary, mice strains DB-A and Swiss developed $\mathrm{PE}$ lesions and shed the bacteria, especially when inoculated with pure culture.

This information can be useful for the establishment of an experimental model for PE infection and reinforce the potential risk that mice pose in the transmission of $L$. intracellularis.

Acknowledgements,- This study was supported by funds from Fapemig (CVZ-APQ-01743-08) and INCT/IGSPB-CNPq. RMCG was supported by fellowship from Conselho de Desenvolvimento Tecnológico e Científico (CNPq, Brasília, Brazil).

\section{REFERENCES}

Boom R., Sol C.J., Salimans M.M., Wertheim-van Dillen P.M. \& Van der Noordaa J. 1990. Rapid and simple method for purification of nucleic acids. J. Clin. Microbiol. 28:495-503.

Boutrup T.S., Boesen H.T., Boye M., Agerholm J.S. \& Jensen T.K. 2010. Early pathogenesis in porcine proliferative enteropathy caused by Lawsonia intracellularis. J. Comp. Pathol. 143:101-109.

Collins A.M., Fell S., Pearson H. \& Toribio J.A. 2011. Colonization and shedding of Lawsonia intracellularis in experimentally inoculated rodents and in wild rodents on pig farms. Vet. Microbiol. 150:384-388.

Collins A.M., Love R.J., Jasni S. \& McOrist S. 1999. Attempted infection of mice, rats and chickens by porcine strains of Lawsonia intracellularis. Aust. Vet. J. 77:120-122.

Cooper D.M. \& Gebhart C.J. 1998. Comparative aspects of proliferative enteritis. J. Am. Vet. Med. Assoc. 212:1446-1451.

Cooper D.M., Swanson D.L., Barns S.M. \& Gebhart C. 1997. Comparison of the $16 \mathrm{~S}$ ribosomal DNA sequence from the intracellular agent of proliferative enteritis in a hamster, deer, and ostrich with the sequence of a porcine isolate of Lawsonia intracellularis. Int. J. Syst. Bacteriol. 47:635639.

Fitzwater W.D. 1994. House sparrows, in: Prevention and control of wildlife damage. <http://hgic.clemson.edu/PDF/PCWDHOUSE_SPARROWS. pdf> Accessed on Sept. 16, 2009.

Fortier A., Min-Oo G., Forbes J., Lam-Yuk-Tseung S. \& Gros P. 2005. Single effects in mouse models of host: pathogen interactions. J. Leukoc. Biol. 77:868-877.

Friedman M., Bednar V., Klimes J., Smola J., Mrlík V. \& Literák I. 2008. Lawsonia intracellularis in rodents from pig farms with the occurrence of porcine proliferative enteropathy. Lett. Appl. Microbiol. 47:117-121.

Gebhart C. \& Guedes R.M.C. 2004. Lawsonia intracellularis, p.363-372, In: Gyles C.L., Prescott J.F., Songer J.G., Thoen C.O. (Eds), Pathogenesis of Bacterial Infections in Animals. Blackwell Publishing Press, Oxford.

Go Y.Y., Lee J.K., Ye J.Y., Lee J.B., Park S.Y., Song C.S., Kim S.K. \& Choi I.S. 2005. Experimental reproduction of proliferative enteropathy and the role of IFN-gamma in protective immunity against Lawsonia intracellularis in mice. J. Vet. Sci. 6:357-359.
Guedes R.M.C. \& Gebhart C.J. 2003a. Comparison of intestinal mucosal homogenate and pure culture of the homologous Lawsonia intracellularis isolate in reproducing proliferative enteropathy in swine. Vet. Microbiol. 93:159-166.

Guedes R.M.C. \& Gebhart C.J. 2003b. Onset and duration of fecal shedding, cell-mediated and humoral immune responses in pigs after challenge with a pathogenic isolate or attenuated vaccine strain of Lawsonia intracellularis. Vet. Microbiol. 91:135-145.

Guedes R.M.C. \& Gebhart C.J. 2003c. Preparation and characterization of polyclonal and monoclonal antibodies against Lawsonia intracellularis. J. Vet. Diagn. Invest. 15:438-446.

Jacobson M., Fellström C. \& Jensen-Waern M. 2010. Porcine Proliferative enteropathy: an important disease with questions remaining to be solved. Vet. J. 184:264-268.

Jones G.F., Ward G.E., Murtaugh M.P., Lin G. \& Gebhart C.J. 1993. Enhanced detection of intracellular organism of swine proliferative enteritis, Ileal symbiont intracellularis, in feces by polymerase chain reaction. J. Clin. Microbiol. 31:2611-2615.

Kroll J.J., Roof M.B., Hoffman L.J., Dickson J.S. \& Harris D.L.H. 2005. Proliferative enterophaty: a global enteric disease of pigs caused by Lawsonia intracellularis. Anim. Health Res. Rev. 6:173-197.

Lawson G.H.K. \& Gebhart C.J. 2000. Proliferative enteropathy: A review. J. Comp. Pathol. 122:77-100.

Lemarchand T.X., Tully Jr T.N., Shane S.M. \& Duncan D.E. 1997. Intracellular Campylobacter-like organisms associated with rectal prolapse and proliferative enteroproctitis in emus (Dromaius novaehollandiae). Vet. Pathol. 34:152-156.

Macintyre N., Smith D.G.E., Shaw D.J., Thomson J.R. \& Rhind S.M. 2003. Immunopathogenesis of experimentally induced proliferative enteropathy in pigs. Vet. Pathol. 40:421-432.

McOrist S., Gebhart C.J., Boid R. \& Barns S.M. 1995. Characterization of Lawsonia intracellularis gen. nov, sp nov, the obligately intracellular bacterium of porcine proliferative enteropathy. Int. J. Syst. Bacteriol. 45:520-525.

Murakata K., Sato A., Yoshiya M., Kim S., Watarai M., Omata Y. \& Furuoka H. 2008. Infection of different strains of mice with Lawsonia intracellularis derived from rabbit or porcine proliferative enteropathy. J. Comp. Pathol. 139:8-15.

Olsen S.C., Thoen C.O. \& Cheville N.F. 2004. Brucella, p.309-320. In: Gyles C.L., Prescott J.F., Songer J.G. \& Thoen C.O. (Eds), Pathogenesis of Bacterial Infections in Animals. Blackwell Publishing Press, Oxford.

Pusterla N., Mapes S., Rejmanek D. \& Gebhart C. 2008. Detection of Lawsonia intracellularis by real-time PCR in the feces of free-living animals from equine farms with documented occurrence of equine proliferative enteropathy. J. Wildl. Dis. 44:992-998.

Pusterla N., Mapes S. \& Gebhart C. 2012. Further investigation of exposure to Lawsonia intracellularis in wild and feral animals captured on horse properties with equine proliferative enteropathy. Vet. J. (Ahead of printing)

Segalés J., Fernández-Salguero J.M., Fructuoso G., Quintana J., Rosell C., Pozo J., De Arriba M.L., Rubio P. \& Domingo M. 2001. Granulomatous enteritis and lymphadenitis in Iberian pigs naturally infected with Lawsonia intracellularis. Vet. Pathol. 38:343-346.

Smith D.G.E. \& Lawson G.H.K. 2001. Lawsonia intracellularis: getting inside the pathogenesis of proliferative enteropathy. Vet. Microbiol. 82:331345.

Smith D.G.E., Mitchell S.C., Nash T. \& Rhind S. 2000. Gamma interferon influences intestinal epithelial hyperplasia caused by Lawsonia intracellularis infection in mice. Infect. Immun. 68:6737-6743.

Vanucci F.A., Borges E.L., Oliveira J.S.V. \& Guedes R.M.C. 2010. Intestinal absorption and histomorphometry of Syrian hamsters (Mesocricetus auratus) experimentally infected with Lawsonia intracelullaris. Vet. Microbiol. 145:286-291.

Vanucci F.A., Pusterla N., Mapes S.M. \& Gebhart C. 2012. Evidence of host adaptation in Lawsonia intracellularis infections. Vet. Res. 43:43-53. 